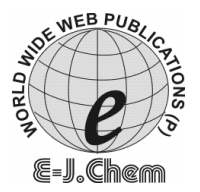

http://www.e-journals.net
CODEN ECJHAO

E-Journal of Chemistry

Vol. 3, No.1, pp 25-27, January 2006

\title{
Spectrophotometric Method for the Determination of Oxaliplatin in Pure and Dosage Forms
}

\author{
G.SRINUBABU ${ }^{1}$, D.PUNDARIKA RAO ${ }^{2}$, L. SRIDHAR $^{1}$ \\ and J.V.L.N. SESHAGIRI RAO ${ }^{1} *$ \\ ${ }^{1}$ University College of Pharmaceutical Sciences, \\ ${ }^{2}$ Department of Geo-engineering, College of Engineering. \\ Andhra University, Visakhapatnam -530003 (A.P.) INDIA.
}

Received 2 October 2005; Accepted 23 January 2006

\begin{abstract}
A simple and reproducible spectrophotometric method has been developed for the estimation of Oxaliplatin in pure and dosage forms. The method is based on the reaction of the drug with 1, 10 Phenanthroline in presence of ferric chloride, which forms a blood red colored complex exhibiting maximum absorption at $520 \mathrm{~nm}$.
\end{abstract}

Key words:. Oxaliplatin, spectrophotometric method

\section{Introduction}

Oxaliplatin ([( $1 \mathrm{R}, 2 R)-1,2$-cyclohexanediamine-N, $N]$ oxalato (2-)-O, $O$-platinum) is a novel platinum complex which in combination with other chemotherapeutics has a significant cytostatic activity for metastatic colon cancer ${ }^{1}$. The pharmacokinetics of Oxaliplatin has so far almost exclusively been based on analysis of the platinum content in plasma and ultra filtrate using flameless atomic absorption spectroscopy (FAAS) or inductively coupled plasma mass spectrometry (ICPMS) ${ }^{2}$. However, analytical techniques measuring the concentration of platinum will codetermine the parent compound as well as other cytotoxic and biologically inactive biotransforma-tion products. Recently, the kinetics of Oxaliplatin in plasma ultra filtrate from patients was studied using liquid chromatography followed by fraction collection and measuring the platinum content by FAAS ${ }^{3}$. Liquid chromatography with porous graphitic carbon (PGC) has previously been utilized for the preparative isolation ${ }^{4-6}$ and quantitative analysis ${ }^{7-9}$ of Pt-containing cytotoxic agents in 
pure aqueous solutions. Until now there is no single spectrophotometric method available in the literature for oxaliplatin determination.

26 J.V.L.N. SESHAGIRI RAO et al.

The authors now report the development of simple and reproducible spectrophotometric method for its determination in pure and dosage forms. Spectrophotometric parameters were established for standardization of the method by statistical analysis of data.

\section{Experimental}

All the chemicals used were of analytical grade. Solution of 1,10 Phenanthroline monohydrate $(0.2 \%)$ and ferric chloride $(0.5 \%)$ were prepared using double distilled water. Spectral and absorbance measurements were made on an Elico UV-Visible spectrophotometer (Model 64) with $10 \mathrm{~mm}$-matched quartz cells.

\section{Preparation of standard solution}

$100 \mathrm{mg}$ of pure Oxaliplatin was accurately weighed and dissolved in $100 \mathrm{ml}$ of double distilled water to get a concentration of $1 \mathrm{mg} / \mathrm{ml}$. This solution was further diluted with water to get a working standard solution of $100 \mu \mathrm{g} / \mathrm{ml}$.

\section{Preparation of sample solution}

A commercial brand of injection was chosen. For this, 5 injections were taken and from that Oxaliplatin equivalent to $50 \mathrm{mg}$ was transferred to a $50 \mathrm{ml}$ volumetric flasks containing 25 $\mathrm{ml}$ methanol. The contents were allowed to stand for $1 / 2 \mathrm{~h}$ with intermittent sonication to ensure complete solubility of the drug and then filtered through $0.45 \mu \mathrm{m}$ membrane filter. The volume was made to the mark with methanol. The solution is suitably diluted with methanol to get $100 \mu \mathrm{g} / \mathrm{ml}$.

\section{Method}

Aliquots of standard solution were transferred into a series of $10 \mathrm{ml}$ calibrated tubes. To that $0.5 \mathrm{ml}$ of ferric chloride and $2.5 \mathrm{ml}$ of Phenanthroline were added and heated on a boiling water bath for $15 \mathrm{~min}$. contents were cooled to room temperature and $1 \mathrm{ml}$ of orthophosphoric acid added. Finally the volume was adjusted with distilled water and absorbance was measured at $520 \mathrm{~nm}$ against a reagent blank prepared under identical conditions.

\section{Results and Discussion}

The optical characteristics such as Beer's law limits, Sandell's sensitivity, molar extinction coefficient, percent relative standard deviation and percent range of error were calculated for the method and the results are summarized in Table 1. The accuracy of the methods was ascertained by comparing the results of the proposed methods with that of reported method. In order to justify the reliability and suitability of proposed methods, a known amount of pure drug was added to its various pre analyzed dosage forms and was analyzed by the proposed method. The results presented in Table 2 indicate that the proposed method can be successfully applied for the analysis of Oxaliplatin in dosage forms. The additives and excipients usually present in pharmaceutical preparations did not interfere.

\section{Chemistry of the colored species}

The present method is based on the formation of blood red colored complex ( $\lambda$ max: 520 $\mathrm{nm})$ with ferric chloride after its reduction to ferrous form. The blood red colored complex resulting from Oxaliplatin may be due to the fact that each of the two nitrogen atoms has an unshared pair of electrons that can be shared with Fe (II) ion formed by the reaction of 
Oxaliplatin with Fe (III). Three such molecules of PTL attach themselves by means of dative bonds (Ferroin complex).

Spectrophotometric Method for the Determination of Oxaliplatin

Table 1. Optical characteristics

\begin{tabular}{ll}
\hline Parameters & Value \\
\hline Beer's law limits $(\mu \mathrm{g})$ & $8-32$ \\
Sandell's sensitivity $\left(\mu \mathrm{g} / \mathrm{cm}_{2} / 0.001\right.$ absorbance unit) & 0.049 \\
Molar absorbtivity & 8070 \\
\% Relative standard deviation & 0.3467 \\
\% Range of error & \\
0.05 Confidence limits & 0.285 \\
0.01 Confidence limit & 0.484 \\
Correlation coefficient & 0.99912 \\
Regression equation $(\mathrm{Y}=\mathrm{b}+\mathrm{ac})^{*}$ & \\
$\quad$ Slope (a) & 0.021 \\
Intercept (b) & -0.0066
\end{tabular}

*where $\mathrm{C}$ is the concentration in $\mu \mathrm{g} / \mathrm{ml}$ and $\mathrm{Y}$ is absorbance unit.

Table 2. Assay of Oxaliplatin in Pharmaceutical Formulations

\begin{tabular}{|c|c|c|c|c|}
\hline \multirow[t]{2}{*}{ Sample } & \multirow{2}{*}{$\begin{array}{l}\text { Labelled } \\
\text { amount (mg) }\end{array}$} & \multicolumn{2}{|c|}{ Amount obtained (mg) } & \multirow{2}{*}{$\begin{array}{l}\text { \% recovery by the } \\
\text { proposed method }\end{array}$} \\
\hline & & reference method* & proposed method & \\
\hline 1. Oxaliplatil & 100 & 99.97 & 100.13 & 100.13 \\
\hline
\end{tabular}

*UV method developed by authors

\section{Acknowledgements}

The authors are thankful to Dr. Reddys, for providing a gift sample of Oxaliplatin for this investigation.

\section{References}

1. Misset J L, Bleiberg H, Sutherland W, Bekradda M and Cvitkovic E, Crit. Rev. Oncol. Hematol., 2000, 35, 75

2. Graham M A, Lockwood G F, Greenslade D, Brienza S, Bayssas M and Gamelin E, Clin. Cancer Res., 2000, 6, 1205.

3. Shord S S, Bernard S A, Lindley C, Blodgett A, Mehta V, Churchel M A, Poole M, Pescatore S L, Luo F R and Chaney S G, Anticancer Res., 2002, 22, 2301.

4. Ehrsson H, Wallin I, Andersson A and Edlund P O. Anal. Chem., 1995, 67, 3608.

5. Yachnin J, Wallin I, Lewensohn R, Sirzen F and Ehrsson H, Cancer Lett.,1998, 132, 175

6. Ekborn A, Lindberg A, Laurell G, Wallin I, Eksborg S and Ehrsson H, Cancer Chemother. Pharmacol., 2003, 51, 36.

7. Videhult P, Yachnin J, Jerremalm E, Lewensohn R and Ehrsson H, Cancer Lett., 2002, 180, 191.

8. Jerremalm E, Videhult P, Alvelius G, Griffiths W J, Bergman T, Eksborg S and Ehrsson H, J. Pharm. Sci. 2002, 91., 2116.

9. Jerremalm E, Eksborg S and Ehrsson H, J. Pharm. Sci., 2003, 92, 436. 


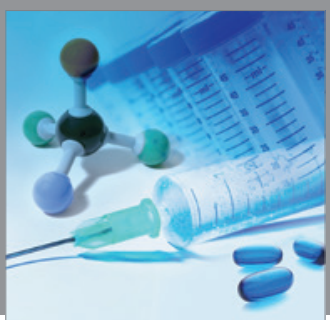

International Journal of

Medicinal Chemistry

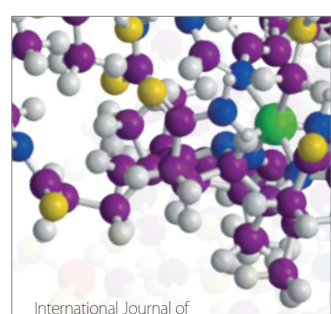

Carbohydrate Chemistry

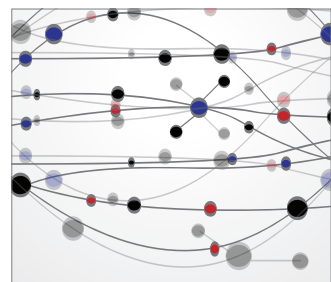

The Scientific World Journal
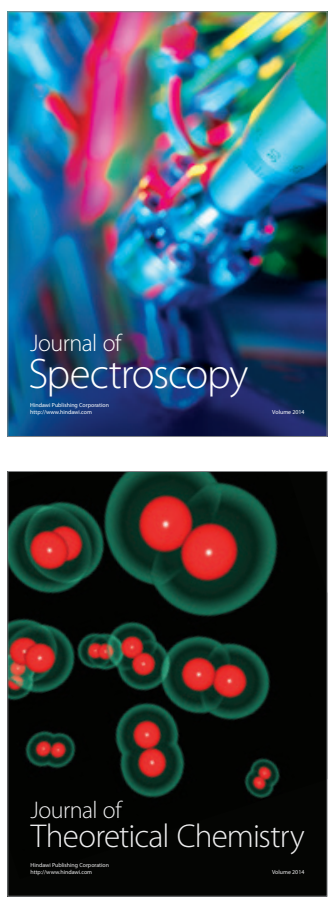
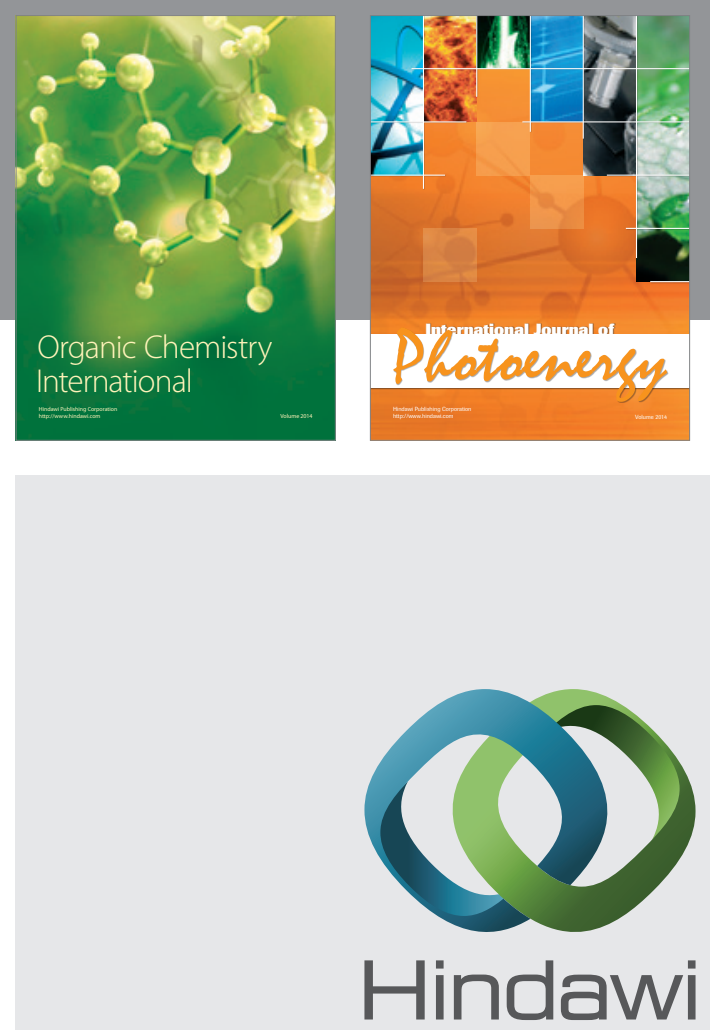

Submit your manuscripts at

http://www.hindawi.com
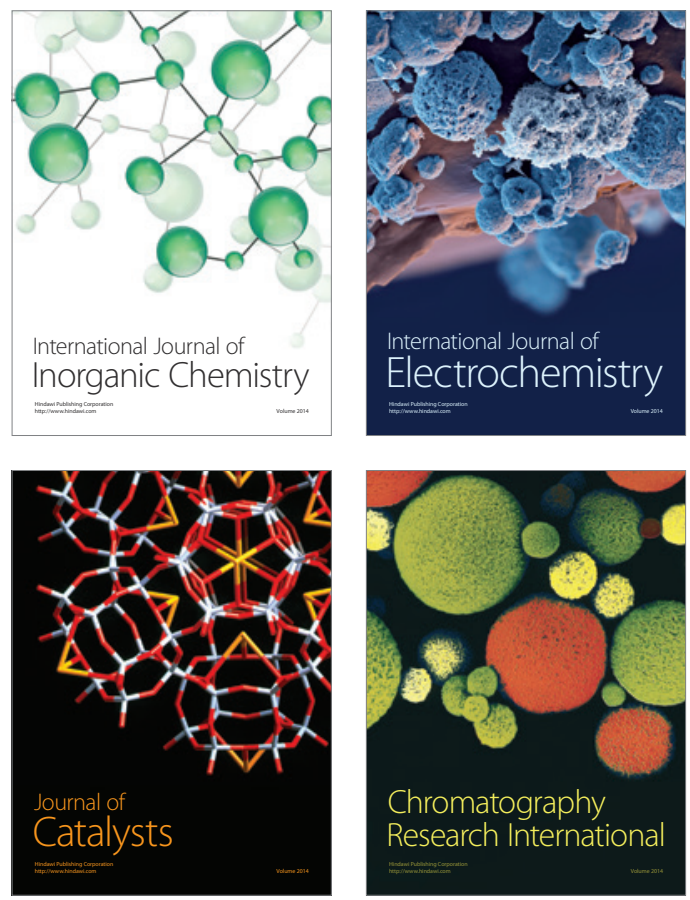
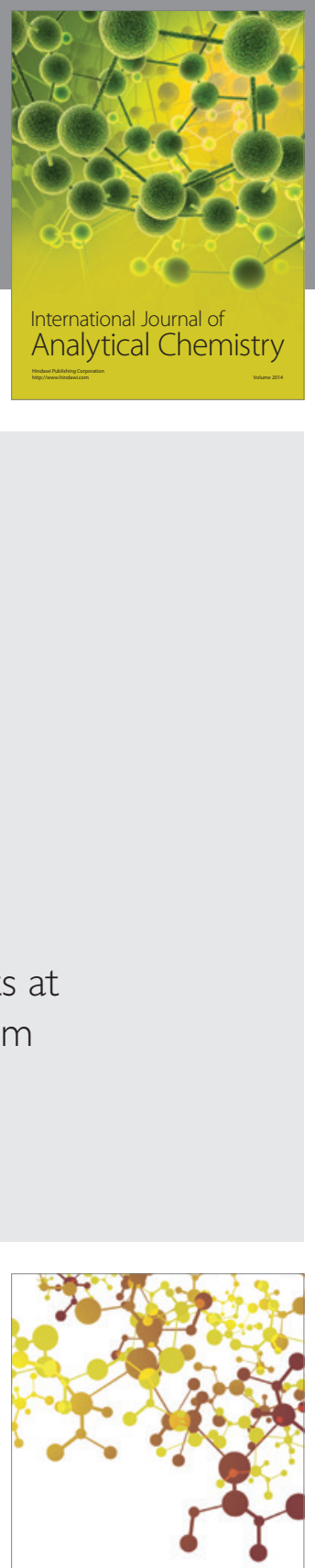

Journal of

Applied Chemistry
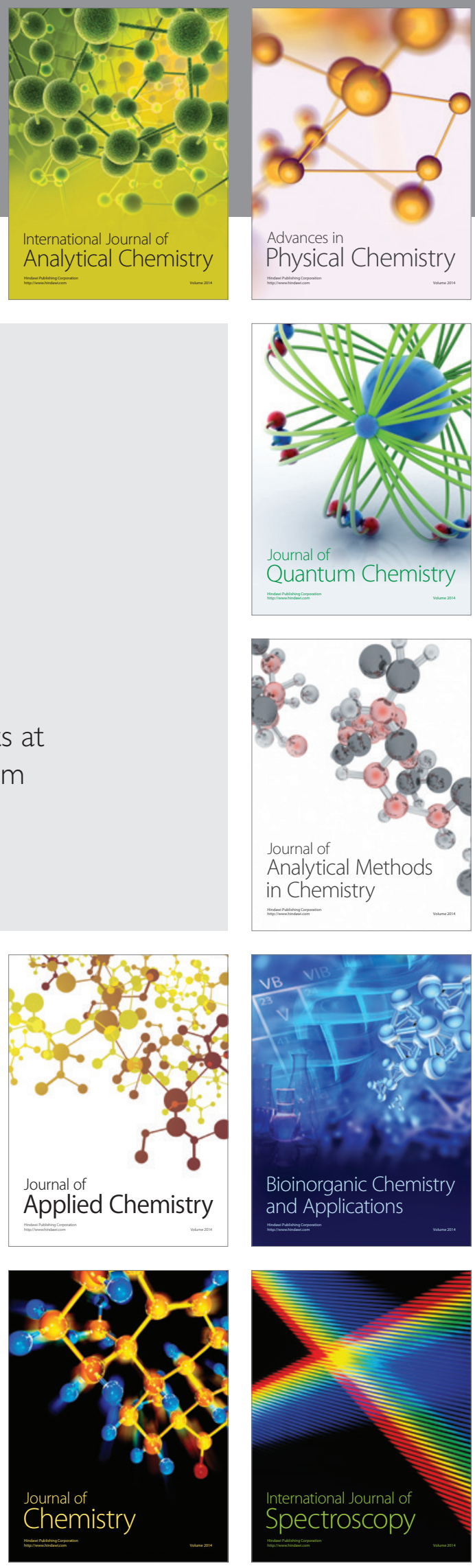